\title{
(221) 制覆実験モデルのパラメタ同定
}

東電設計（株） ○吉田郁政 黒瀬浩公 福井史朗

\section{1.あえがき}

土木・建築構造物への制震技術の適用性の研究が、数值シミュレーションと実験の両側面から数多く行わ れている。制震の実験あるいは実構造物への制震技術の適用を行う場合、対象構造物の動的特性を的確にと らえておくことが重要である。アクティブマスダンバー（以下AMDと記す）による制震のモデル実験を行 うに当たって、その実験モデルの動的特性の同定を行なった。用いた同定手法は星谷らによる繰り返しカル マンフィルター"である。対象としたパラメタはモデルの剛性と減衰であり、AMDの動的特性の同定は対 象外とした。検討ケースとしては、1) AMD固定、振動台加振に対する計測記録による同定、2)振動台固定、 AMD加振に対する計測記録による同定、の2種類を考えた。実構造物では1) は常時微動、地震観測記録か らの同定、2) は起振実験による同定に相当すると考えられる。

\section{2.制展実験モデルの概要}

実験に用いた入力地震動は 2 種類であり、その加速度蛙刻歴と加速度フーリエスペクトルを目ー $1 、 2$ に 示す。入力 1 は比較的広い範囲の周波数成分を含んでいるのに対し、入力 2 は $3 \mathrm{~Hz}$ 付近に卓説した成分を 有している。振動台に設置された実験モデルは図ー3に示すように3枚の鋼板からなり4本の鋼棒で支えら れている。高さは各層間 $31 \mathrm{c} \mathrm{m}$ 、計 $93 \mathrm{~cm}$ で、重量は約 $85 \mathrm{~kg} \mathrm{f}$ である。AMDは最上層に取り付け られており、可動マスの重量は $3.5 \mathrm{~kg}$ fである。各層及び振動台には速度計が、AMDの可動マスには 加速度計が取り付けられている。

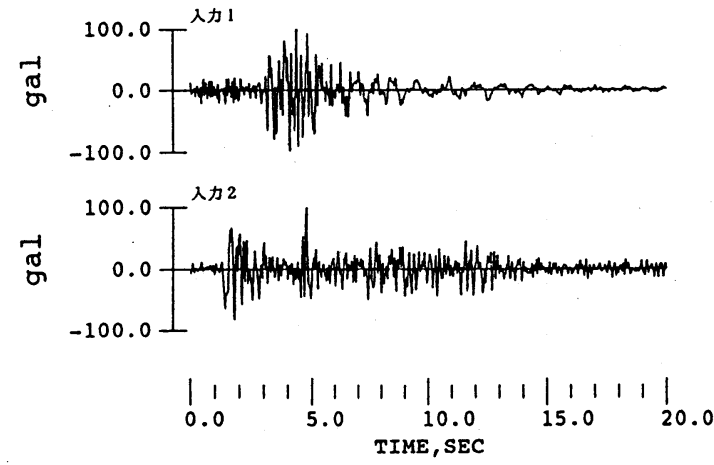

目-1 入力の加速度時刻歷

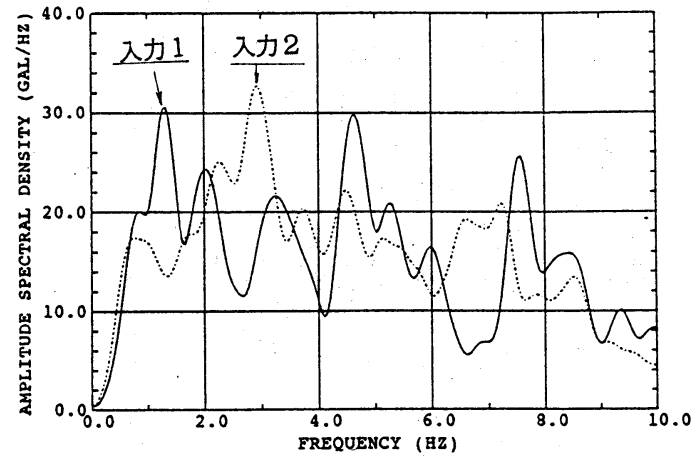

図-2 入力の加速度フーリエスペクトル

\section{3.振動台加振によるパラメタ同定}

AMDを固定して、振動台による加振を行い各層の応答時刻歴を求 めた。その際の入力は 2 .に示した 2 波である。用いたパラメタ同定 の手法は繰り返しカルマンフィルターであり、定式化の方法は星谷ら 1) と同様である。ただし、未知量の共分散マトリックスについては、 グローバルイタレーションで更新せず初期化した点で、星谷らの $\mathrm{E} \mathrm{K}$ 一WG I 法と異なる。パラメタ同定の対象としたのは各層の剛性と減 衰であり、剛性の初期值は材料定数から定め、減衰については $1 \%$ と 仮定した。

まず、全層の応答時刻歴を観測量としてパラメタ同定を行った。入

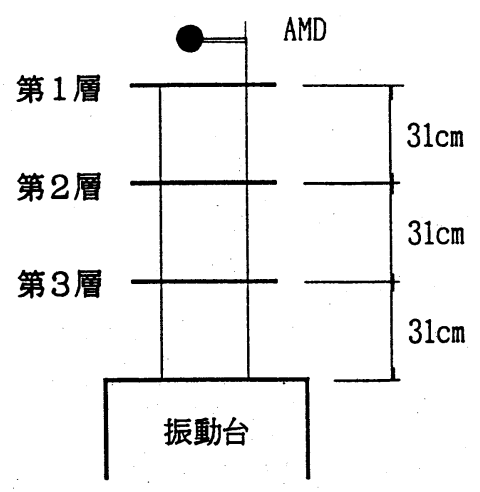

困ー3 実験モデル 
カ 1 に対する収束過程を困 -4 に示す。用いた手法はオンライン方式なので各タイムステップごとにパラメ タが改良される。剛性は 10 秒ぐらいで、減衰は 15 秒ぐらいで安定している。最終時刻のパラメタを初期 值とした同定を収束值が得られるまで繰り返した。今回行なったケースではだいたい数回のイタレーション で収束した。第1層についての実験による応答時刻歷と、初期モデル（同定を行う前のモデル）及び改良モ デル (同定計算の収束結果のモデル) による時刻歴の比較を図ー 5 に示す。初期モデルも最初の 10 秒ぐら いまではよく一致しているが、後半にずれが見られる。それに対し、改良モデルでは後半部もよく一致して いる。次に全層についてのスペクトル比（各層の応答／入力）の比較を図ー6に示す。スペクトル比も全体 的に改良されており、特に1次のピークの適合度が改善されていることがわかる。

入力 2 に対しても同様にパラメタ同定を行った。同定された剛性, 減衰を図一 7 に示す。結果は、入力 1 の場合とほぼ同様である。剛性は上から順に大きい傾向が見られる。減衰については同定結果のバラッキは 大きいが、ほぼ一様の值が得られた。次に 1 層の計測記録だけを用いてパラメタの同定を行った。同定結果 の剛性, 減衰も図一7に示した。第 1 層 の計測記録だけを用いた場合は、入力 1 に対しても入力 2 に対しても収束值が得 られなかった。図ー6に示したスペクト ル比からわかるように、第 1 層の応答は 1 次モードが非常に卓越しており、高次 モードの情報がそしいことが原因と考え られる。第2 層あるいは第3層の計測記 録を用いた場合は収束しており、剛性に ついてはこれまでとほぼ同様な結果が得 られた。減衰についてはばらつきが大き く、剛性の同定に比べて不安定なことが

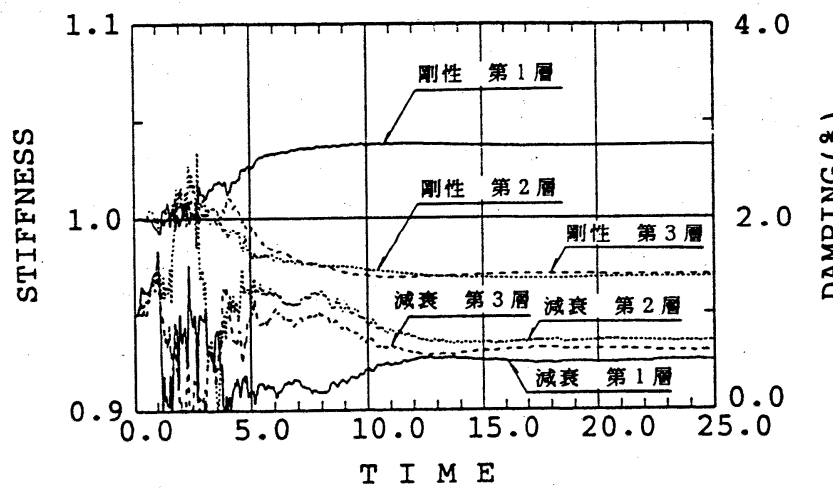

図-4 収束過程（入力 1、全層観測） わかる。

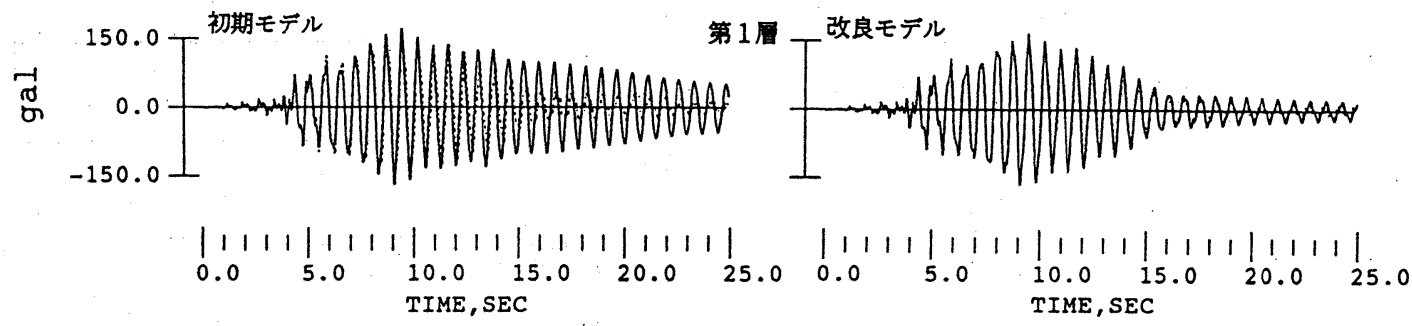

囚ー5 初期モデル及び改良モデルによる加速度応答時刻歴の比較（振動台加振）
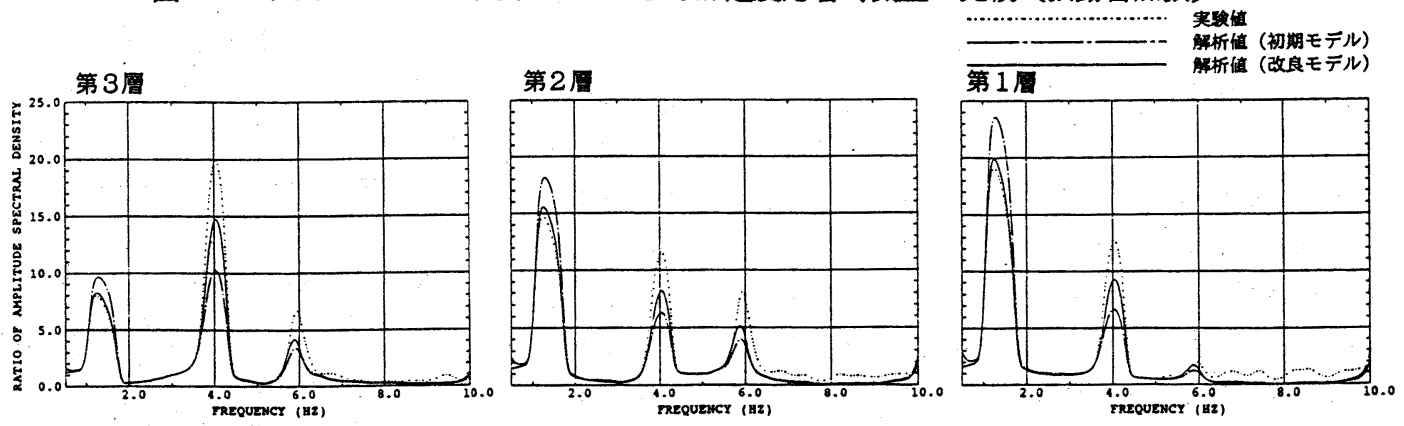

因一－初期モテル及び改良モデルによるスペクトル比の比較（振動台加振） 
同定

次に振動台を固定してAMD による加振を行い応答時刻歴を 求め、剛性と減衰の同定を行っ た。前節と同様に 2 種類の入力 地震動, 観測点が 3 点の場合と 1 点の場合、その組み合わせで 計 8ケースについて同定を行っ た。第 1 層を観測点とした場合

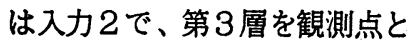
した場合は入力 1 で収束值が得 られなかった。それ以外のヶー スでは数回のグローバルイタレ

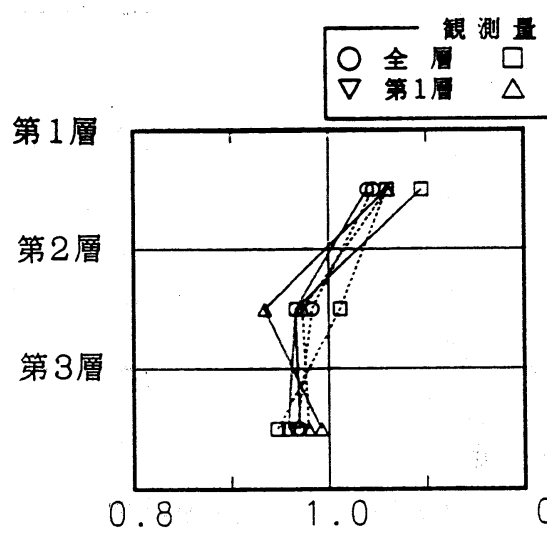

剛性の推定値／初期值
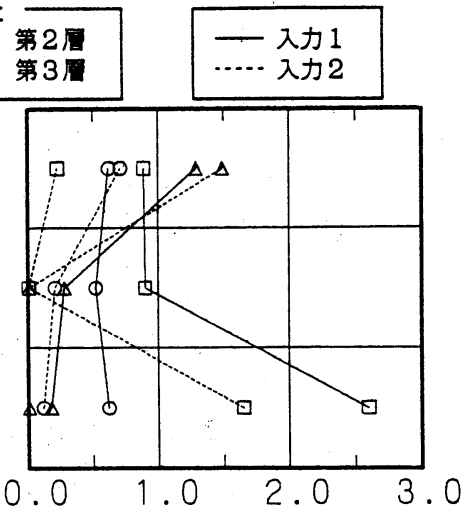

減 衰 (\%)

困-7 同定された剛性、減衰の比較（振動台加振）

ーションて紧克している。入力 1 、全層を観測点とした場合の応答時刻歷の比較を図ー 8 に入力に対する スペクトル比の比較を図ー9に示す。また同定された剛性、減衰の比較を目ー 10 に示す。初期モデルによ る結果は時刻歴もスペクトル比も実験結果と傾向が異なる。振動台加振の場合は 1次のスペクトル比は実験 よりも大きく、2、3次のスペクトル比は逆に小さかったのに対し、AMD加振の場合はスペクトル比全体 が実験結果より小さくなっている。時刻歷も全体的に実験結果よりも振幅が小さい。改良モデルでは時刻歷 の一致度も良好であるし、スペクトル比も 1 次、2次はよく一致している。全層を観測量とした同定結果は、 剛性がやや小さいものの振動台加振の場合とほぼ同様の結果が得られた。1 層だけを観測量とした場合にも 上部の方が剛性が大きいという特徵はとらえられているが、振動台加振の場合に比べ (減衰も含め) 同定結 果のばらつきが大きい。
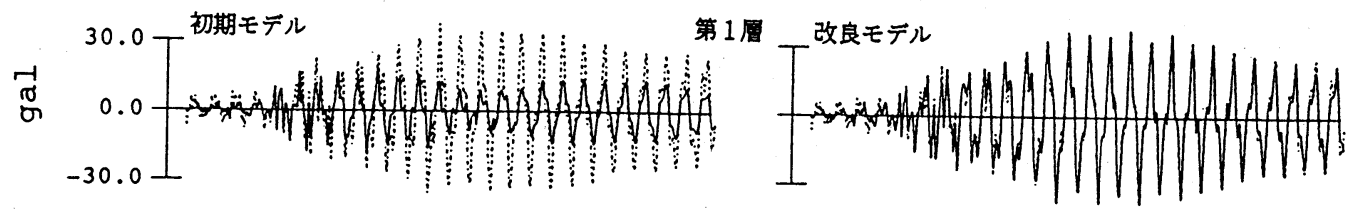

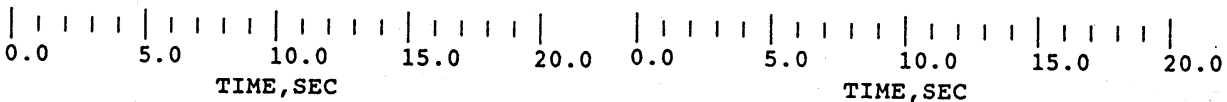

図-8 初期モデル及び改良モデルによる加速度応答時刻歴の比較 (AMD加振)
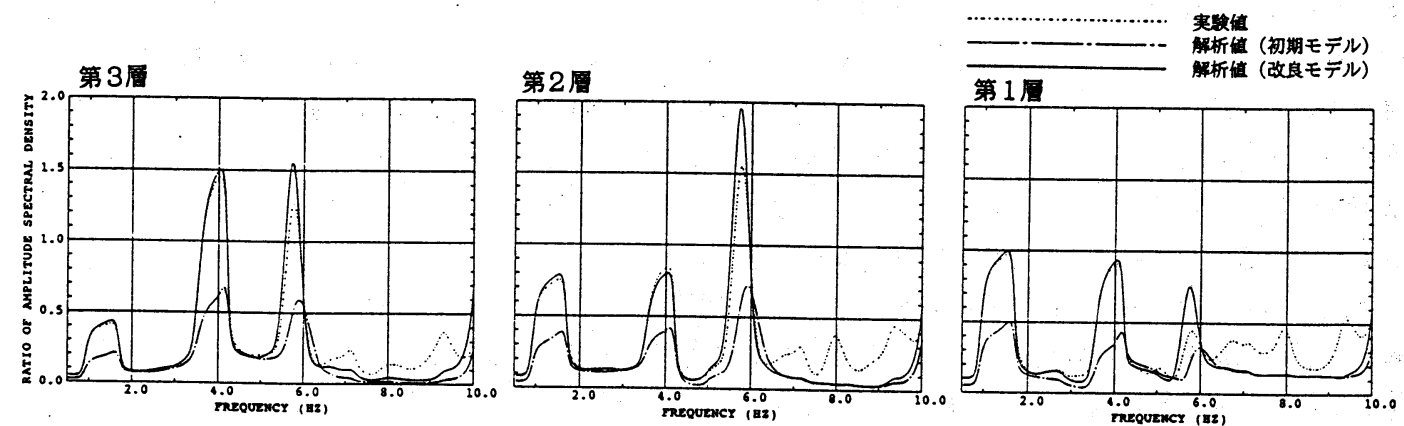

困-9＼cjkstart初期モテル及び改良モデルによるスペクトル比の比較（AMD加振） 


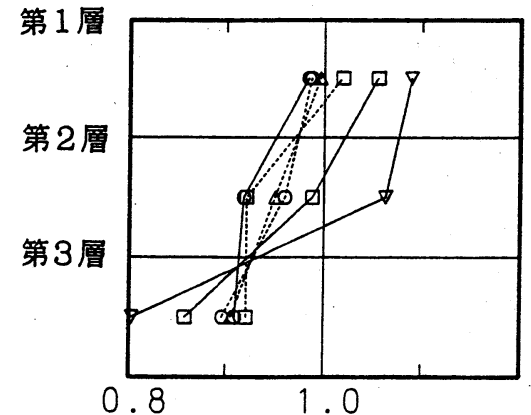

剛性の推定值/初期值

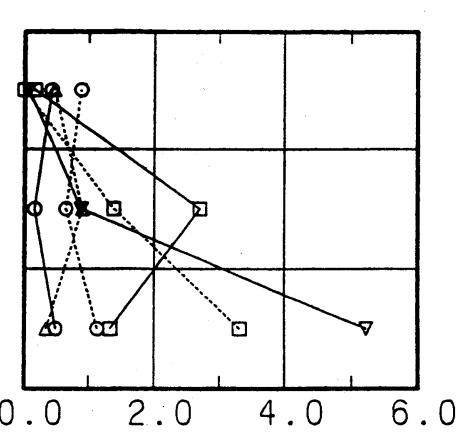

減 衰 (\%)

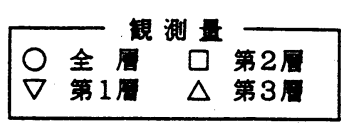

凶-10 同定された剛性、減衰の比較 (AMD加振)

\section{5 . 制㫳実験のシミュレーション}

改良したモデル（全層観測、振動台加振のケース）を用いてAMDによる制震実験のシミュレーションを 行った。制御実験は、Direct Velocity Foedback による制御ゲインを数種類設定し、入力 $1 、 2$ に対して行 なった。シミュレーションで求めたト・ーザオフ萿線と実験結果の比較を図ー 11 に示す。縦軸は応答值 (状態量) の r m s 值を無制震の場合の応答で基準化した量、横軸は制御力の $\mathrm{r} \mathrm{m} \mathrm{s}$ 值を入力加速度の $\mathrm{r} \mathrm{m}$ $\mathrm{s}$ 值に構造物の総質量を乗じた量で基準化した量を表している。従って縦軸の 1 .0は制震効果が全くない ことに、横軸の1.0は地震外力を完全に相殺するのに必要な力に相当する。困一 11 によると、シミュレーシ ヨン結果と実験結果はほぼ一致しており、シミュレーションによって制御成績の評価ができることがわかる。
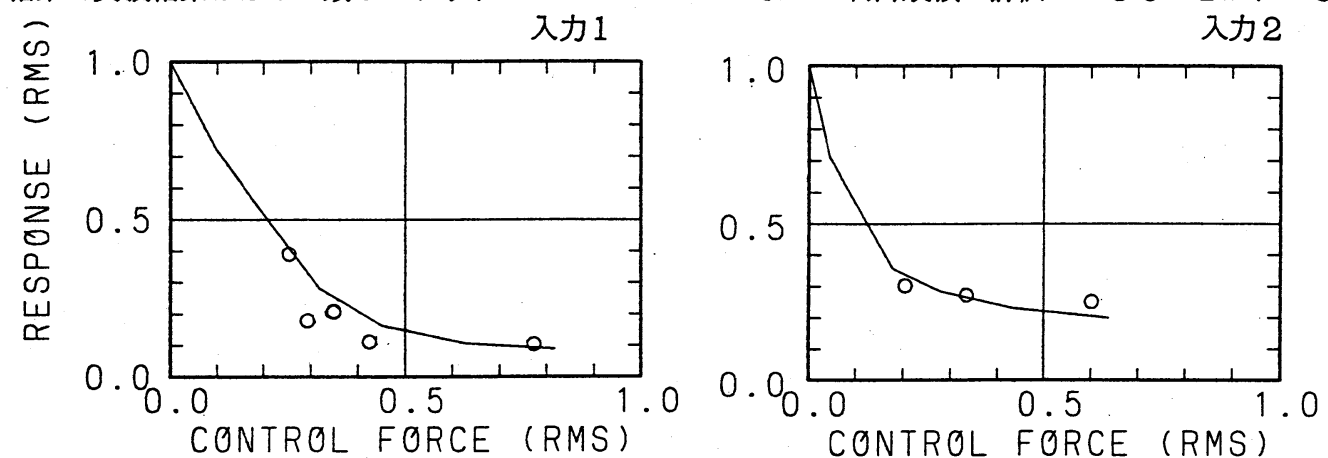

6.おわりに

困-11 トレードオフ曲線による実験とシミュレーションの比較

振動台による起振の場合も、AMDによる起振の場合も実験モデルの動的特性を同定することができ、シ ミュレーションの精度を向上できることがわかった。ただし、観測点が一点の場合は不安定になり、収束が 得られない場合があった。また、AMD加振の場合に比へ、振動台加振の場合の同定の方が収束值のばらつ きが小さく安定していることがわかった。今回示した例では初期值が収束值に比較的近かったが、初期值を 意識的にずらして同定を行なっても同じ収束值を得ることができた。従って、実構造物のように事前に十分 な情報がない場合にも当手法が適用できると期待される。制震実験についても、ほぼ良好に数值シミュレー ションできることがわかり、その有効性が確認できた。

武藏工学大学星谷教授には同定問題全般にわたって議論していただき有益な助言をいただいた。京都大学 家村助教授には有益なご意見とともに、京都大学で実験を行うに当たって多くの便宜を計っていただいた。 また、同大学院生見坂茂範君に実験を行う上で御助力をいただいた。ここに謝意を表します。

看文献 1)星谷勝・斉藤悦郎：拡張カルマンフィルターを用いた各種振動系への応用, 土木学会論文報 告菓, 第339号、 1983 